\title{
Monocytes Do Not Inhibit Peripheral Blood Erythroid Burst Forming Unit Colony Formation
}

\author{
Jeffrey M. Lipton, Nan A. Link, Jacqueline Breard, Pamela L. Jackson, \\ Bryan J. Clarke, and David G. NAThan, Division of Hematology and Oncology, \\ Children's Hospital Medical Center, Division of Pediatric Oncology and \\ Division of Tumor Immunology, Sidney Farber Cancer Institute, and \\ Department of Pediatrics, Harvard Medical School, Boston, Massachusetts 02115
}

A в S T R A C T To determine a possible role of peripheral blood monocytes in erythroid differentiation, various fractions of peripheral blood mononuclear cells were prepared from normal volunteers. The fractions contained 3-95\% monocytes. These freshly prepared monocytes did not inhibit erythroid burst forming unit expression in plasma clot erythroid colony culture. Null cell preparations contaminated by up to $84 \%$ monocytes expressed erythroid burst forming unit colony formation when either $\mathrm{T}$ lymphocytes or $\mathrm{T}$-cell conditioned medium was added. These results indicate that certain peripheral blood null cells engage the program of erythroid differentiation in the presence of $T$ cells and erythropoietin. Monocytes do not inhibit this engagement.

\section{INTRODUCTION}

Recent studies of erythroid colony growth in culture suggest that certain murine and erythroid progenitors differentiate in response to collaboration between $\mathrm{T}$ cells or their products and erythropoietin (1-4). This collaboration has been well-demonstrated in cultures of the erythroid burst forming unit (BFU-E) ${ }^{1}$ found in human peripheral blood mononuclear cells (2). These primitive erythroid progenitors give rise to large colonies of hemoglobinized cells consisting of multiple subcolonies. Optimal growth occurs from day 11 to 14 in plasma clot. The progenitors have a relatively high erythropoietin requirement, synthesize more fetal hemoglobin than marrow erythroid progenitors, and are less sensitive to tritiated thymidine suicide. They are thought to represent a primitive class of erythroid

Received for publication 10 July 1979 and in revised form 31 August 1979.

${ }^{1}$ Abbreviations used in this paper: $\alpha$-, alpha medium minus nucleosides; BFU-E, erythroid burst forming unit(s); FACS, fluorescence-activated cell sorter; LMF, lymphocyte mitogenic factor. progenitors, closer in ontogeny to the pluripotent stem cell than are the majority of marrow erythroid progenitors (5).

To determine whether large numbers of monocytes may inhibit BFU-E colony growth in culture as suggested (6), we have investigated the effect of monocytes on the growth and differentiation of human peripheral blood BFU-E colonies. In the culture system used for these studies, we find no inhibition of BFU-E colony growth in preparations of peripheral blood mononuclear cells or null cells in which monocytes comprise up to $95 \%$ of the population.

\section{METHODS}

Human subjects. Blood was obtained after informed consent from six completely normal adult males ranging in age from 24 to $49 \mathrm{yr}$.

Cell processing and fractionation. Peripheral blood was obtained in $10 \mathrm{U} / \mathrm{ml}$ preservative-free heparin and immediately diluted in an equal volume of alpha medium (Grand Island Biological Co., Grand Island, N. Y.) minus nucleosides $(\alpha-) .25 \mathrm{ml}$ of diluted blood was layered atop $20 \mathrm{ml}$ of FicollPaque (Pharmacia Fine Chemicals, Piscataway, N. J.) and then centrifuged at $400 \mathrm{~g}$ at $18^{\circ} \mathrm{C}$ for $35 \mathrm{~min}$. The layer of nucleated cells at the plasma-Ficoll-Paque interface was harvested and thrice washed in $\alpha$-medium. This initial Ficoll-Paque separation, expectedly rich in monocytes (7), was designated as fraction $I$.

Fraction II was prepared from fraction I cells suspended in $\alpha$ - and $20 \%$ fetal calf serum (Flow Laboratories, Rockville, $\mathrm{Md}$.) at a cell concentration of $4 \times 10^{6} / \mathrm{ml} .10 \mathrm{ml}$ of this preparation were incubated for $1 \mathrm{~h}$ at $37^{\circ} \mathrm{C}$ in a $100 \times 15-\mathrm{mm}$ plastic Petri dish (Falcon Labware, Div. Becton, Dickinson \& Co., Oxnard, Calif.). The nonadherent cells were pipetted off the dish. In one experiment, a fraction called IIA was prepared. This included fraction II cells plus all of the cells obtained from the Petri dish after it was thrice washed by vigorous shaking with $10 \mathrm{ml}$ of $\alpha$-. Fraction III was obtained by removal of the remaining adherent cells from the plastic Petri dish. This removal was accomplished by the addition of $6 \mathrm{ml}$ of a solution of $30 \mathrm{mM}$ lidocaine (Astra Pharmaceutical Products, Inc., Worcester, Mass.) and $10 \%$ fetal calf serum in $\alpha$-followed by incubation for $15 \mathrm{~min}$ at room temperature (6). The re- 
leased cells were decanted and the dish twice rinsed with 10 $\mathrm{ml}$ of $\alpha$-. The adherent fraction that remained after preparation of fraction IIA was released as described above and called fraction IIIA.

Cytology viability and function. Cells of different fractions were taken to a concentration of $\sim 2 \times 10^{5} / \mathrm{ml}$ in $\alpha$ - and $5 \%$ fetal calf serum, cytocentrifuged (Shandon Southern Instruments Inc. Sewickley, Pa.), at $1,000 \mathrm{rpm}$ for $6 \mathrm{~min}$ and stained with Wright-Giemsa and for peroxidase activity (8). 200-300 cell differentials were performed. Differentials obtained by peroxidase and Wright-Giemsa staining were equivalent. These differentials were used to calculate the lymphocyte and monocyte content of all fractions plated in plasma clot.

To evaluate monocyte function and viability before and after separation, trypan blue exclusion and nitro blue tetrazolium reduction $(9,10)$ were assayed in samples of each fraction. Trypan blue exclusion was regularly $96-100 \%$ and the percentage of cells capable of nitro blue tetrazolium reduction was roughly equivalent to the percent monocytes obtained on differential count although highly accurate quantitation was not possible because of nitro blue tetrazolium induced monocyte clumping.

Null cell preparations and quantitation. In three experiments, highly purified null and T lymphocytes were prepared from peripheral blood mononuclear cells (fraction I) by a modification (2) of the immunoabsorbant column chromatography and erythrocyte-rosetting procedure previously described (11). No effort was made to remove monocytes from these null cell preparations by adherence procedures. They therefore contained large numbers of monocytes.

Quantitation of monocytes in this null cell fraction was performed with a specific anti-human monocyte serum raised in rabbits (12), with direct immunofluorescence measured with a fluorescence-activated cell sorter (FACS) (Becton, Dickinson FACS Systems, Mountain View, Calif.) (13).

Cell culture. Peripheral blood mononuclear or null cell preparations were plated at cell densities described in Tables I and II in the plasma clot culture system described (14-16) and modified (2). The culture system contained 2 IU of erythropoietin (Connaught step III, Connaught Medical Research Laboratories, Willowdale, Ontario, Canada) per milliliter. In some experiments, lymphocyte mitogenic factor (LMF) prepared from tetanus toxoid stimulated mononuclear cells (2) was substituted for NCTC-109 (Microbiological Associates, Bethesda, Md.) as $10 \%$ of the plasma clot culture.

Clotting was initiated by the addition of $0.1 \mathrm{ml}$ of NCTC-109 containing $1 \mathrm{U}$ of grade 1 bovine thrombin (Sigma Chemical Co., St. Louis, Mo.). The $1.0 \mathrm{ml}$ of clotting mixture was dispensed in $0.1-\mathrm{ml}$ aliquots into $0.2-\mathrm{ml}$ microtiter culture wells (Linbro plates; Linbro Scientific Co., New Haven, Conn.) and incubated under $5 \% \mathrm{CO}_{2}$ in high humidity.

The plasma clots were incubated for up to $14 \mathrm{~d}$. On day 14, the clots were fixed and stained as described by McLeod and coworkers (14). Erythroid colonies in four to six clots were counted and the results expressed as the mean and standard error of the mean of the number of erythroid colonies per $10^{5}$ cells plated.

\section{RESULTS}

BFU-E proliferation as a function of monocyte concentration in fractions of peripheral blood mononuclear cells. The data in Table I present the results of the study of each individual both as BFU-E colonies per $10^{5}$ lymphocytes plated and as BFU-E growth per milliliter of plasma clot for each fraction with and with- out the addition of LMF. In this way the effects of mixtures of fractions with different lymphocyte contents could be compared. The calculated expected values for each mixture based on the addition of each separate component is shown in the last two columns of the table. All subjects demonstrated BFU-E colonies in fractions I, II, and IIA. There was no striking LMF effect on colony growth in these fractions. More importantly, BFU-E colonies were expressed in fractions III and IIIA (75-97\% monocytes) in all four subjects, though LMF was required to optimize growth in three. In fact, in three studies the colonies per $10^{5}$ lymphocytes were higher in fraction III than in fractions I and II. There were 19 studies of mixtures of fractions I or II with fraction III, nine of them with LMF addition to optimize growth. In 10 of these studies the actual BFU-E colony recovery was equivalent to the expected recovery calculated from growth of the individual components of the mixtures. In five the recovery was somewhat greater than that expected and in only four was the recovery somewhat less than that expected.

Null cell growth. Table II shows the BFU-E colonies derived from cultures of null cells alone, $\mathrm{T}$ lymphocytes alone, null cells plus $\mathrm{T}$ lymphocytes and null cells plus LMF in three experiments. Cell sorter analysis of null cells revealed that $50-84 \%$ of these cells were monocytes (Fig. 1). T cells or LMF were required for optimal BFU-E colony growth from null cells.

\section{DISCUSSION}

Monocytes and macrophages may play a trophic role in erythropoiesis. This area has been recently reviewed (17). It has been suggested that they may be involved in erythropoietin elaboration or in the passage of other material important to the developing erythocyte. There is morphologic evidence of a nexus between macrophages and erythroid precursors in the bone marrow (18), a physical proximity that could provide a conducive microenvironment for erythroid proliferation. On the other hand, one laboratory has demonstrated an inhibitory effect of large numbers of human monocytes on in vitro peripheral blood BFU-E colony formation (4). There are many reasons why such cells might suppress growth in culture systems. The myriad of trophic and inhibitory monocyte/macrophage products excreted into the extracellular environment has been extensively reviewed (19). In addition, macrophages may be cytotoxic as a result of their elaboration of oxidants (20) or simply because of their effects on the $\mathrm{pH}$ of the medium.

In this study we were unable to demonstrate an inhibitory role of fresh viable functioning monocytes (as evidenced by trypan blue exclusion and stimulated nitro blue tetrazolium reduction) on BFU-E colony forma- 
TABLE I

Effect of Monocytes on BFU-E Expression

\begin{tabular}{|c|c|c|c|c|c|c|c|c|}
\hline \multirow{3}{*}{$\begin{array}{l}\text { Donor } \\
\text { fraction }\end{array}$} & \multirow{3}{*}{$\begin{array}{l}\text { Cells } \\
\text { plated } \\
\text { ml clot }\end{array}$} & \multirow[b]{3}{*}{ Monocytes } & \multirow{2}{*}{\multicolumn{2}{|c|}{$\begin{array}{c}\text { BFU-E colonies } \\
\text { per } 10^{5} \text { lymphocyte }\end{array}$}} & \multicolumn{4}{|c|}{ BFU-E colonies/ml } \\
\hline & & & & & \multicolumn{2}{|c|}{ actual } & \multicolumn{2}{|c|}{ expected } \\
\hline & & & $+\mathrm{LMF}$ & - LMF & $+\mathrm{LMF}$ & $-\mathrm{LMF}$ & $+\mathrm{LMF}$ & -LMF \\
\hline & & $\%$ & & & & & & \\
\hline \multicolumn{9}{|c|}{ S.O. } \\
\hline I & $2 \times 10^{6}$ & 61 & $34.2 \pm 11.5$ & $21.8 \pm 5.1$ & $267 \pm 90$ & $170 \pm 78$ & - & - \\
\hline II & $2 \times 10^{6}$ & 3 & $26.1 \pm 3.8$ & $7.4 \pm 3.7$ & $506 \pm 73$ & $144 \pm 72$ & & \\
\hline III & $10^{6}$ & 85 & $11.3 \pm 8.0$ & $0 \pm 0$ & $17 \pm 12$ & $0 \pm 0$ & & \\
\hline $\begin{array}{l}\text { I+ } \\
\text { III }\end{array}$ & $\begin{array}{l}2 \times 10^{6} \\
5 \times 10^{5}\end{array}$ & 66 & $39.6 \pm 9.9$ & $11.4 \pm 5.5$ & $337 \pm 84$ & $97 \pm 47$ & $276 \pm 87$ & $170 \pm 78$ \\
\hline $\begin{array}{l}\text { II+ } \\
\text { III }\end{array}$ & $\begin{array}{r}2 \times 10^{6} \\
10^{6}\end{array}$ & 30 & - & $19 \pm 4$ & - & $399 \pm 84$ & - & $144 \pm 72$ \\
\hline $\begin{array}{l}\text { II+ } \\
\text { III }\end{array}$ & $\begin{array}{l}2 \times 10^{6} \\
5 \times 10^{5}\end{array}$ & 19 & $19.5 \pm 4.3$ & $30.4 \pm 2.6$ & $395 \pm 87$ & $616 \pm 53$ & $515 \pm 72$ & $144 \pm 72$ \\
\hline \multicolumn{9}{|l|}{ J.L. } \\
\hline I & $2 \times 10^{6}$ & 56 & $7.6 \pm 1.4$ & $12 \pm 2$ & $67 \pm 12$ & $106 \pm 18$ & - & - \\
\hline II & $10^{6}$ & 6 & $3.7 \pm 1.4$ & $2 \pm 0.4$ & $35 \pm 13$ & $19 \pm 4$ & - & - \\
\hline III & $10^{6}$ & 80 & $47 \pm 6$ & $13 \pm 6.5$ & $94 \pm 12$ & $26 \pm 13$ & - & - \\
\hline $\begin{array}{l}\text { I+ } \\
\text { III }\end{array}$ & $\begin{array}{l}2 \times 10^{6} \\
5 \times 10^{5}\end{array}$ & 61 & $14.7 \pm 1.6$ & $14.6 \pm 0.9$ & $143 \pm 16$ & $142 \pm 9$ & $114 \pm 9$ & $119 \pm 17$ \\
\hline $\begin{array}{l}\text { II }+ \\
\text { III }\end{array}$ & $\begin{array}{r}10^{6} \\
5 \times 10^{5}\end{array}$ & 31 & $15.6 \pm 2$ & $20 \pm 1.1$ & $161 \pm 21$ & $207 \pm 11$ & $82 \pm 9$ & $32 \pm 5$ \\
\hline \multicolumn{9}{|l|}{ P.B. } \\
\hline I & $2 \times 10^{6}$ & 31 & $24.6 \pm 5.1$ & $8.7 \pm 0.4$ & $340 \pm 70$ & $120 \pm 6$ & - & - \\
\hline II & $10^{6}$ & 4 & $25 \pm 4.6$ & $21.1 \pm 4.5$ & $240 \pm 44$ & $203 \pm 43$ & - & - \\
\hline IIA & $10^{6}$ & 10 & $38.9 \pm 4.4$ & $30 \pm 5.2$ & $350 \pm 40$ & $270 \pm 47$ & - & - \\
\hline III & $10^{5}$ & 81 & $94.7 \pm 13$ & $28.4 \pm 3.2$ & $90 \pm 12$ & $27 \pm 3$ & - & - \\
\hline IIIA & $10^{5}$ & 95 & $132 \pm 36$ & $52 \pm 36$ & $33 \pm 9$ & $13 \pm 9$ & - & - \\
\hline $\begin{array}{l}\text { I+ } \\
\text { III }\end{array}$ & $\begin{array}{l}2 \times 10^{6} \\
5 \times 10^{5}\end{array}$ & 41 & $51.5 \pm 5.4$ & $6.3 \pm 0.5$ & $760 \pm 80$ & $92.5 \pm 7.5$ & $430 \pm 58$ & $147 \pm 5$ \\
\hline $\begin{array}{l}\text { I+ } \\
\text { IIIA }\end{array}$ & $\begin{array}{l}2 \times 10^{6} \\
5 \times 10^{5}\end{array}$ & 44 & $27.1 \pm 10.7$ & $5.5 \pm 3.4$ & $380 \pm 150$ & $77 \pm 48$ & $373 \pm 65$ & $133 \pm 6$ \\
\hline $\begin{array}{l}\text { II+ } \\
\text { III }\end{array}$ & $\begin{array}{r}10^{6} \\
5 \times 10^{5}\end{array}$ & 30 & $31 \pm 3.7$ & $19 \pm 5.7$ & $326 \pm 39$ & $200 \pm 60$ & $330 \pm 35$ & $230 \pm 38$ \\
\hline $\begin{array}{l}\text { IIA+ } \\
\text { IIIA }\end{array}$ & $\begin{array}{r}10^{6} \\
5 \times 10^{5}\end{array}$ & 38 & $39 \pm 4.3$ & $30 \pm 6$ & $362 \pm 40$ & $279 \pm 56$ & $383 \pm 37$ & $283 \pm 45$ \\
\hline \multicolumn{9}{|l|}{ D.N. } \\
\hline I & $2 \times 10^{6}$ & 29 & $17.7 \pm 2.8$ & $25.9 \pm 2.3$ & $252 \pm 40$ & $368 \pm 32$ & - & - \\
\hline II & $10^{6}$ & 8 & $25.2 \pm 2.4$ & $27.9 \pm 3.0$ & $232 \pm 22$ & $257 \pm 28$ & - & - \\
\hline III & $5 \times 10^{5}$ & 79 & $135 \pm 14$ & $186 \pm 21$ & $142 \pm 15$ & $195 \pm 22$ & - & - \\
\hline $\begin{array}{l}\text { II+ } \\
\text { III }\end{array}$ & $\begin{array}{r}10^{6} \\
5 \times 10^{5}\end{array}$ & 32 & $26.5 \pm 4.2$ & $39.9 \pm 1.6$ & $270 \pm 43$ & $406 \pm 16$ & $374 \pm 19$ & $452 \pm 25$ \\
\hline
\end{tabular}

tion. As well, T-cell dependent BFU-E colony growth from peripheral blood null cells, a phenomenon previously described (2), occurred even though the null cells were contaminated with $84 \%$ monocytes. Indeed, with the procedures that we employed, we found that peripheral blood mononuclear cells heavily contaminated with monocytes still give rise to BFU-E colony growth even at monocyte concentrations as high as $\mathbf{9 5 \%}$. If the monocytes were present to the near exclusion of lympho- cytes, LMF addition was required to promote optimal growth. But if lymphocytes (presumably $\mathrm{T}$ cells) were present, in sufficient numbers, BFU-E colony growth readily occurred at monocyte concentrations of $\sim 40-80 \%$.

There are several reasons why our results might differ from those gathered in another laboratory. Physical techniques designed to separate lymphocytes from monocytes are known to be inadequate (21). In fact, our separation procedures frequently led to segrega- 
TABLE II

BFU-E Colonies Derived from Null Cells in the Presence of T Lymphocytes or LMF

\begin{tabular}{|c|c|c|c|c|c|c|}
\hline \multirow[b]{2}{*}{ Population } & \multicolumn{3}{|c|}{ Number cells plated $/ \mathrm{ml}$ plasma clot } & \multicolumn{3}{|c|}{ BFU-E $/ 10^{5}$ cells plated $*$} \\
\hline & $\begin{array}{l}\text { Experi- } \\
\text { ment } 1 \ddagger\end{array}$ & $\begin{array}{l}\text { Experi- } \\
\text { ment } 2 \S\end{array}$ & $\begin{array}{l}\text { Experi- } \\
\text { ment } 3 \S\end{array}$ & $\begin{array}{l}\text { Experi- } \\
\text { ment } 1\end{array}$ & $\begin{array}{l}\text { Experi- } \\
\text { ment } 2\end{array}$ & $\begin{array}{l}\text { Experi- } \\
\text { ment } 3\end{array}$ \\
\hline Null cells & $2 \times 10^{5}$ & $2 \times 10^{5}$ & - & $41.5 \pm 7.5$ & $30 \pm 6$ & - \\
\hline Null cells & $8 \times 10^{4}$ & $2 \times 10^{5}$ & $10^{5}$ & $41.3 \pm 15$ & 0 & 0 \\
\hline T lymphocytes & $10^{6}$ & $10^{6}$ & - & $3 \pm 1.7$ & $1 \pm 0.4$ & 0 \\
\hline Null cells and & $2 \times 10^{5}$ & $10^{5}$ & $10^{5}$ & & & \\
\hline T lymphocytes & $10^{6}$ & $10^{6}$ & $10^{6}$ & $170 \pm 10$ & $183 \pm 24$ & $180 \pm 20$ \\
\hline $\begin{array}{l}\text { Null cells and } \\
\text { T lymphocytes }\end{array}$ & $\begin{array}{r}8 \times 10^{4} \\
10^{6}\end{array}$ & - & - & $229 \pm 11$ & - & - \\
\hline $\begin{array}{l}\text { Null cells and } \\
\text { LMF }\end{array}$ & $2 \times 10^{5}$ & $10^{5}$ & - & $220 \pm 9$ & $143 \pm 8$ & - \\
\hline $\begin{array}{l}\text { Null cells and } \\
\text { LMF }\end{array}$ & $8 \times 10^{4}$ & $5 \times 10^{4}$ & - & $188 \pm 15$ & $140 \pm 10$ & - \\
\hline
\end{tabular}

* For null cell: T-lymphocyte mixtures this is expressed as BFU-E $/ 10^{5}$ null cells plated. $\$$ The null cells contain $84 \%$ monocytes and $\sim 5 \% \mathrm{~T}$ cells as determined by FACS. $\S$ The null cells contain $>50 \%$ monocytes and $\sim 5 \% \mathrm{~T}$ cells as determined by FACS.

tion of BFU-E in the adherent fraction. In addition, some fractions required LMF for optimal growth indicating loss of helper cells (2) during cell separations. Finally, the erythropoietin used in these experiments was prepared from the plasma of phenylhydrazinetreated sheep. Human urinary erythropoietin was used by the workers who demonstrated monocyte inhibition

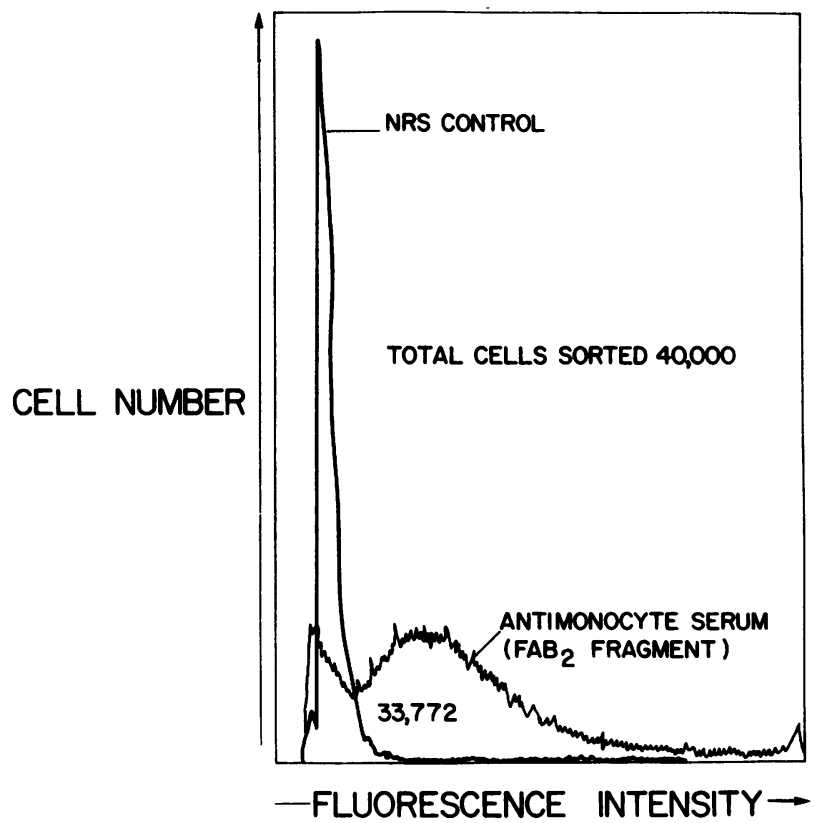

FIGURE 1 FACS analysis of monocyte content of peripheral blood null cells. Analysis was done using fluorescinated $\mathrm{Fab}_{2}$ fragments from an antisera to human monocytes raised in rabbits (9). A total of 40,000 cells were sorted. NRS, normal rabbit serum control. of BFU-E expression in culture. Neither of these preparations are pure. They contain variable amounts of endotoxin (22), and one or another may stimulate monocytes to secrete any number of inhibitors (19) or potential competitors including colony-stimulating activity $(23,24)$.

One of the most likely inhibitors produced by monocytes is prostaglandin E. Monocytes may secrete prostaglandin $\mathrm{E}$ after stimulation by $\mathrm{Fc}$ fragments of immunoglobulin G, zymosan, and endotoxin (25). Because prostaglandin $E$ is known to suppress the division of human $\mathrm{T}$ cells, and thereby influence lymphokine secretion $(26-28)$, it is quite possible that variations in the endotoxin contamination of erythropoietin in the culture medium in different laboratories could lead to different expressions of BFU-E formation if large numbers of monocytes exist in the medium.

The above consideration leads us to the conclusion that although conditions may be created in vitro in which monocytes can inhibit BFU-E colony formation, such inhibition does not necessarily occur and has not occurred in the studies performed in our laboratory. Monocytes therefore do not play an important inhibitory role in the control of erythropoiesis in vitro unless they are activated by certain procedures or reagents. Whether monocytes influence erythrocyte production in vivo is currently not known.

\section{ACKNOWLEDGMENTS}

We wish to thank Dr. Stuart Schlossman, Ms. Pearl Leavitt, and Dr. Peter Newburger for their assistance.

This work was supported by grants HL-07146 and CA-18662 from the National Institutes of Health and the Amy Potter Memorial Fund, National Institutes of Health AM 15322. 


\section{REFERENCES}

1. Iscove, N. N. 1978. Erythropoietin-independent stimulation of early erythropoiesis in adult marrow cultures by conditioned media from lectin-stimulated mouse spleen cells. In ICN-UCLA Symposium on Hematopoietic Cell Differentiation. Molecular and Cell Biology, Academic Press, Inc., New York. 10: 37-52.

2. Nathan, D. G., L. Chess, D. G. Hillman, B. Clarke, J. Breard, E. Merler, and D. E. Housman. 1978. Human erythroid burst forming unit: T-cell requirement for proliferation in vitro. J. Exp. Med. 47: 324-339.

3. Johnson, G. F., and D. Metcalf. 1977. Pure and mixed erythroid colony formation in vitro stimulated by spleen conditioned medium with no detectable erythropoietin. Proc. Natl. Acad. Sci. U. S. A. 74: 3879-3882.

4. Golde, D. W., N. Bersch, S. G. Quan, and M. B. Belzer. 1979. Erythroid potentiating activity produced by a T-lymphocyte cell line. Clin. Res. 27: 461A. (Abstr.)

5. Lipton, J. M., and D. G. Nathan. 1980. T cells and erythropoiesis. Proceedings of Conference on Aplastic Anemia, June 17-19, 1979. In press.

6. Rinehart, J. J., E. D. Zanjani, B. Nomdedeu, B. J. Gormus, and M. E. Kaplan. 1978. Cell-cell interaction in erythropoiesis. Role of human monocytes. J. Clin. Invest. 62: 979-986.

7. Zucker-Franklin, D. 1974. The percentage of monocytes among mono-nuclear cell fractions obtained from normal blood. J. Immunol. 112: 234-240.

8. Kaplow, L. S. 1965. Simplified myeloperoxidase stain using benzidine dihydrochloride. Blood. 26: 215-219.

9. Baehner, R. I., and D. G. Nathan. 1968. Quantitative nitroblue tetrazolium test in chronic granulomatous disease. N. Engl. J. Med. 278: 971-976.

10. Newburger, P. E., M. E. Chovaniec, J. S. Greenberger, and H. J. Cohen. 1979. Functional changes in human leukemic cell line HL-60. A model for myeloid differentiation. J. Cell Biol. 82: 315-322.

11. Chess, L., and S. F. Schlossman. 1976. Methods for preparation of unique human lymphocyte populations. In Manual of Clinical Immunology. N. R. Rose and H. Friedman, editors. American Society for Microbiology. Washington, D. C. 77-80.

12. Breard, J., H. Lazarus, and S. F. Schlossman. 1979. Generation and specificity of an heteroantiserum to human peripheral blood monocytes. Federation of American Societies for Experimental Biology. 1418. (Abstr.)

13. Benna, W. A., H. R. Hulett, R. G. Sweet, and L. A. Herzenberg. 1972. Fluorescence-activated cell sorting. Rev. Sci. Instrum. 43: 404-409.

14. McLeod, D. L., M. M. Shreeve, and A. A. Axelrad. 1974. Improved plasma culture system for production of erythrocytic colonies in vitro: quantitative assay method for CFU-E. Blood. 44: 517-534.
15. Clarke, B. J., and D. E. Housman. 1977. Characterization of an erythroid precursor cell of high proliferative capacity in normal human peripheral blood. Proc. Natl. Acad. Sci. U. S. A. 74: 1105-1109.

16. Tepperman, A. D., J. E. Curtis, and E. A. McCulloch. 1974. Erythropoietic colonies in cultures of human marrow. Blood. 44: 659-669.

17. Cline, M. J., and D. W. Golde. 1979. Cellular interactions in haematopoiesis. Nature (Lond.). 277: 177-181.

18. Bessis, M., C. Mize, and M. Prenant. 1978. Erythropoiesis: comparison of in vivo and in vitro amplification. Blood Cells. 4: 155-174.

19. Unanue, E. R., D. I. Beller, J. Calderon, J. M. Kiely, and M. J. Stadecker. 1976. Regulation of immunity and inflammation by mediators from macrophages. Am. J. Pathol. 85: 465-478.

20. Nathan, C. F., L. H. Brukner, S. C. Silverstein, and Z. A. Cohn. 1979. Extracellular cytolysis by activated macrophages and granulocytes. I. Pharmacologic triggering of effector cells and the release of hydrogen peroxide.J. Exp. Med. 149: 84-99.

21. Blaese, R. M., E. C. Lawrence, and D. G. Poplack. 1977. A critique of techniques of macrophage-monocyte depletion in studies of human peripheral blood mononuclear leukocyte (MNL) function. Proceedings of the 11th Leukocyte Culture Conference. Reprinted from Regulatory Mechanisms in Lymphocyte Activation. Academic Press, Inc. New York. 579-582.

22. Quesenberry, P., J. Levin, K. Zuckerman, N. Rencricca, R. Sullivan, and W. Tyler. 1979. Stem cell migration induced by erythropoietin or haemolytic anemia: the effects of actinomycin and endotoxin contamination of erythropoietin preparations. Br. J. Haematol. 41: 253-269.

23. Cline, M. J., B. Rothman, and D. W. Golde. 1974. Effect of endotoxin on the production of colony stimulating factor by human monocytes and macrophages. J. Cell. Physiol. 94: 193-196.

24. Van Zant, G., and E. Goldwasser. 1977. Simultaneous effects of erythropoietin and colony-stimulating factor on bone marrow cells. Science (Wash. D. C.). 198: 733-736.

25. Passwell, J. H., J. M. Dayer, and E. Merler. 1979. Increased prostaglandin production by human monocytes after membrane receptor activation. J. Immunol. 123: $115-120$.

26. Goodwin, J. S., A. D. Bankhurst, and R. P. Messner. 1977. Suppression of human T-cell mitogenesis by prostaglandin. Existence of prostaglandin-producing suppressor cell. J. Exp. Med. 146: 1719-1734.

27. Goodwin, J. S., R. P. Messner, and G. T. Peake. 1978. Prostaglandin suppression of mitogen-stimulated lymphocytes in vitro. Changes with mitogen dose and preincubation. J. Clin. Invest. 62: 753-760.

28. Gordon, D. M., M. A. Bray, and J. Morley. 1976. Control of leukokine secretion by prostaglandins. Nature (Lond.). 262: 401-402. 